\title{
Use of mortality rates and Hospital Activity Analysis as performance indicators of consultant staffing in thoracic medicine in Wales
}

\author{
P D O DAVIES \\ From Llandough Hospital, Penarth, South Glamorgan
}

ABSTRACT An analysis of data from mortality rates and Hospital Activity Analysis has been used to determine potential "work loads" for respiratory diseases for each health authority in Wales. Mortality rates were generally higher in the authorities with fewer chest physicians in relation to the population. Three health authorities-West Glamorgan, Mid Glamorgan, and Clwyd - stood out as having a very much higher "work load" per chest physician than the other authorities. A fourth, Powys, had no chest physician. Analyses of this nature may be useful in assessing the requirements for medical staffing in any specialty within a region.

\section{Introduction}

The reduction in consultant posts or their equivalents in thoracic medicine in Wales from 32 in $1978^{\prime}$ to 20 in 1986 has given rise to concern that chest services have declined to an unacceptably low level. ${ }^{2}$ To assess the requirements of a service the needs for that service must be quantified. Hospital Activity Analysis provides data on deaths and discharges from hospital based on the International Classification of Diseases ${ }^{3}$ and is published annually by the Office of Population Censuses and Surveys. ${ }^{4}$ These figures provide a useful guide to the work load for a given range of diagnoses, and therefore of staffing requirements within a given specialty, on a district or regional basis.

Standard mortality ratios (SMRs) also provide a good index of disease for a given specialty by area. Data are obtained from death certificates and figures are published annually by the Office of Population Censuses and Surveys, but only on a regional basis. ${ }^{5}$ Only crude mortality rates are published by district health authorities, so the SMR must be calculated separately. Although SMRs give a clearer indication of relative mortality in different diagnostic groups, crude mortality figures are numerical and therefore give a clearer guide to the number of patients treated.

Address for reprint requests: Dr P D O Davies, South Liverpool Chest Clinic, Sefton General Hospital, Liverpool L15 2HE.

Accepted II January 1988
Crude death rates provide a better index of "potential" work load.

I have undertaken a study to determine the staffing needs in thoracic medicine in Wales based on Hospital Activity Analysis and death certification data.

\section{Methods}

Hospital Activity Analysis and crude death rates were obtained from data for Wales for 1981-4 published by the Office of Population Censuses and Surveys. ${ }^{45}$ Population estimates were from the relevant annual monitor of the Office of Population Censuses and Surveys. ${ }^{6}$ The 1978 figures for chest physicians were from a previous survey' and current figures from a simple head count. Numbers are expressed as an average for the four years. Rates have been derived by dividing the total number of deaths by the total population for the four years. Respiratory disease was taken to cover ICD numbers 010-018 (all forms of tuberculosis), 162 (malignant neoplasms of the trachea, bronchus, and lung), and 460-519 (diseases of the respiratory system). ${ }^{3}$

\section{Results}

Crude annual death rates for respiratory disease for all ages per 1000 population by district health authority are shown in figure 1 and in the table. This also gives age specific death rates for the 0-74 year old age groups and discharges and deaths from hospital for respiratory disease per 1000 population by place of residence, together with the number of chest 


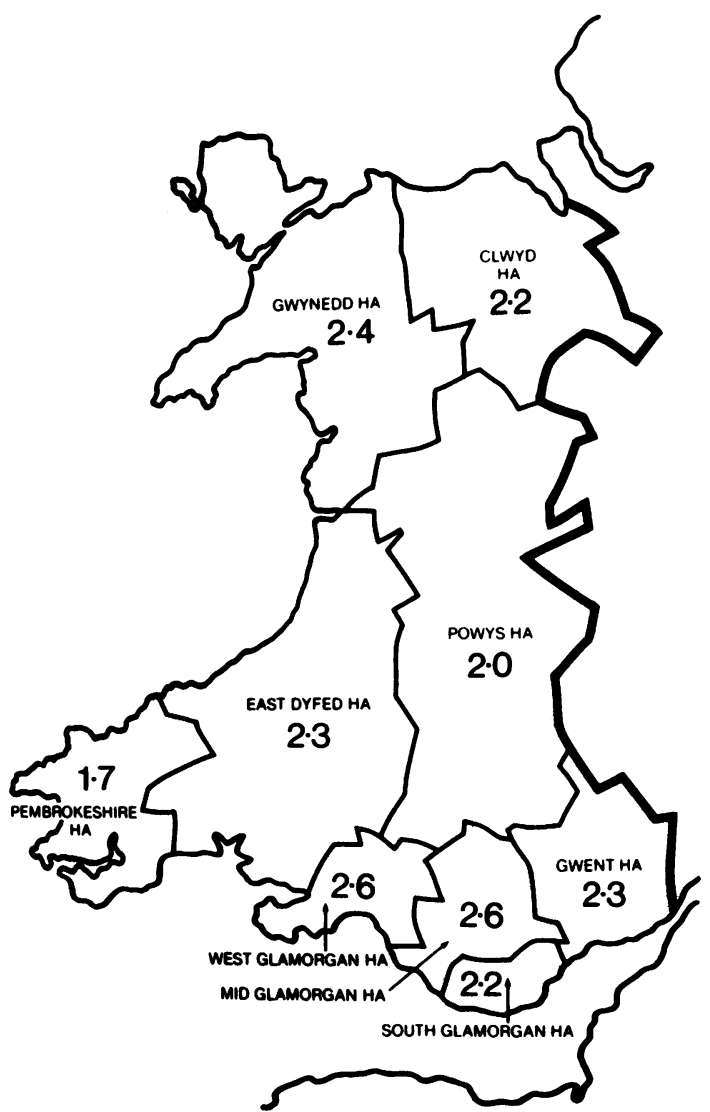

Fig 1 Deaths per 1000 population per year from respiratory disease for each health authority in Wales in 1981-4

physicians or general physicians with an interest in chest medicine in each district and the size of the population covered by chest physicians in the different districts.

The numbers of deaths from respiratory disease per chest physician per year by district health authority (column 6) are derived from the data in columns 1 and $\vec{F}$ 5 . The numbers of individuals aged 0-74 years per? 1000 of that age group dying from a respiratoryc disease per chest physician per year by district health $\bar{\omega}$. authority (column 7) are derived from the data in

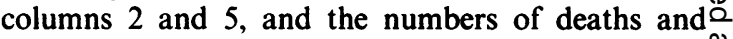
discharges per chest physician by place of residencew (column 8) are derived from the data in columns $3 \vec{\circ}$ and 5 .

A regression analysis of Hospital Activity Analysis $\vec{\rho}$ data of hospital deaths and discharges per year by place of residence against crude death rates for all $\times$ respiratory disease showed a significant relationship $\vec{\omega}$ $(y=0.0793 x+1.19 ; \mathrm{r}=0.69, \mathrm{p}<0.02$-fig 2$)$.

\section{Discussion}

These figures are to some extent theoretical and do notc represent the actual number of patients presenting to chest physicians in Wales. They do provide an $\rightarrow$ estimate, however, of the potential work load which\% could face services for respiratory disease in the nine district health authorities.

This analysis has shown that the distribution of chest physicians does not reflect the distribution of respiratory morbidity and mortality across Wales. Authorities with the highest death rates for respiratory disease - namely, Mid and West Glamorgan-are also $\overrightarrow{\overrightarrow{0}}$ among the authorities with the highest ratio of popula- 3 tion to chest physician. The figures for these authorities may indeed, in practice, be higher than stated as? the greater part of the population of Powys (which has no chest physician) is largely dependent on these authorities for a specialised chest service.

Although the overall figure for Wales of $140000 \frac{3}{3}$ patients to a specialist chest physician appears satisfactory according to British Thoracic Society recom-O mendations, ${ }^{7}$ this does not take account of the higher incidence of respiratory disease in Wales than in England, ${ }^{34}$ or of the fact that 15 of the 20 chest Annual deaths and discharges for 1981-4 for patients with respiratory disease in Wales by district health authority

\begin{tabular}{|c|c|c|c|c|c|c|c|c|}
\hline District & $\begin{array}{l}\text { Deaths/ } \\
1000\end{array}$ & $\begin{array}{l}2 \\
\text { Deaths/ } \\
\text { l000 } \\
\text { aged 0-74 y }\end{array}$ & $\begin{array}{l}3 \\
\text { Deaths and } \\
\text { discharges/ } \\
1000 \text { by } \\
\text { place of } \\
\text { residence }\end{array}$ & $\begin{array}{l}4 \\
\text { No of } \\
\text { chest } \\
\text { physicians }\end{array}$ & $\begin{array}{l}5 \\
\text { Population } \\
\text { per } \\
\text { physician } \\
(1000 s)\end{array}$ & $\begin{array}{l}6 \\
\text { Total } \\
\text { deaths/ } \\
\text { physician }\end{array}$ & $\begin{array}{l}7 \\
\text { Deaths } \\
\text { at } 0-74 \text { y/ } \\
\text { physician }\end{array}$ & $\begin{array}{l}8 \\
\text { Deaths } \\
\text { and } \\
\text { discharges/ } \\
\text { physician }\end{array}$ \\
\hline $\begin{array}{l}\text { Clwyd } \\
\text { East Dyfed } \\
\text { Gwent } \\
\text { Gwynedd } \\
\text { Mid Glam } \\
\text { Pembroke } \\
\text { Powys } \\
\text { South Glam } \\
\text { West Glam } \\
\text { All Wales }\end{array}$ & $\begin{array}{l}2 \cdot 2 \\
2 \cdot 3 \\
2 \cdot 3 \\
2 \cdot 4 \\
2 \cdot 6 \\
1 \cdot 7 \\
2 \cdot 0 \\
2 \cdot 2 \\
2 \cdot 6 \\
2 \cdot 3\end{array}$ & $\begin{array}{l}1.0 \\
1.0 \\
1.2 \\
1.1 \\
1.3 \\
0.9 \\
0.9 \\
1.0 \\
1.2 \\
1.1\end{array}$ & \begin{tabular}{r|}
$13 \cdot 4$ \\
$13 \cdot 2$ \\
$16 \cdot 3$ \\
$14 \cdot 4$ \\
$15 \cdot 5$ \\
$11 \cdot 4$ \\
$8 \cdot 8$ \\
$14 \cdot 5$ \\
$13 \cdot 8$ \\
$14 \cdot 0$
\end{tabular} & $\begin{array}{r}2 \\
2 \\
4 \\
2 \\
3 \\
1 \\
0 \\
4 \\
2 \\
20\end{array}$ & $\begin{array}{l}197 \\
112 \\
110 \\
117 \\
179 \\
107 \\
-100 \\
185 \\
140\end{array}$ & $\begin{array}{l}433 \\
258 \\
253 \\
281 \\
465 \\
182 \\
- \\
220 \\
481 \\
322\end{array}$ & $\begin{array}{l}197 \\
112 \\
132 \\
129 \\
233 \\
103 \\
- \\
100 \\
222 \\
154\end{array}$ & $\begin{array}{l}2630 \\
1480 \\
1790 \\
1680 \\
2770 \\
1220 \\
1450 \\
2550 \\
1960\end{array}$ \\
\hline
\end{tabular}


Death rate/ $1000 /$ year

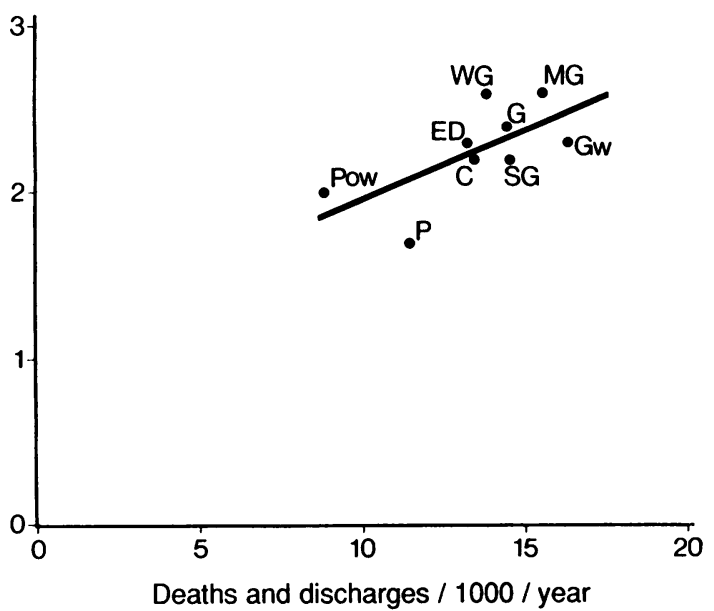

Fig 2 Relation between deaths and discharges for respiratory disease per 1000 per year against death rate for respiratory disease per 1000 population by place of residence for Welsh District Health Authorities in 1981-4 $(r=0.69, p<0.02)$. Pow-Powys; P-Pembrokeshire; ED-East Dyfed; C-Clwyd; WG-West Glamorgan; $G$-Gwynedd; $S G$-South Glamorgan; $M G-M i d$ Glamorgan; $G-G$ went.

physicians in Wales are general physicians with a substantial work load outside thoracic medicine.

The crude death rate includes a substantial proportion of people aged 75 years or more, and these patients are perhaps more likely to present to general practitioners or geriatricians rather than chest physicians. A separate analysis for those aged 0-74 was therefore carried out (column 7). This reduces the number of respiratory deaths per chest physician by about half but does not appreciably alter the striking differences between the districts-more than twofold. The difference between the three districts with the highest numbers of deaths and of deaths and discharges per chest physician (Clwyd, West Glamorgan, and Mid Glamorgan) and the remaining districts is striking (columns 7 and 8 ). These data suggest that further chest physicians are needed in Mid Glamorgan, West Glamorgan, and Clwyd District Health Authorities.

Detailed study of hospital inpatient and mortality statistics provides a good guide to consultant staffing needs in a region. Appointment committees might consider carrying out such an analysis for the relevant diagnostic categories when considering an appointment to any specialty. The significant relation between numbers of deaths and numbers of discharges shown by regression analysis suggests that either measure may be used.

\section{References}

1 Citron KM, Lewis DR, Nunn AJ. Staffing in Thoracic Medicine. Br Med J 1980;281:887-8.

2 Anonymous. Only 16 chest consultants left in Wales. Western Mail 1987; March 16:12.

3 World Health Organisation. International classification of diseases. Vol. 1. Geneva: WHO, 1977.

4 Office of Population Censuses and Surveys. Hospital Inpatient Enquiry. London: HMSO, 1982, 1983, 1984, 1985. (Series MB4, Nos 17-20.)

5 Office of Population Censuses and Surveys. Mortality Statistics (area). London: HMSO, 1982, 1983, 1984, 1985. (Series DH5, Nos 8-11.)

6 Office of Population Censuses and Surveys. Population estimates. (Series PP1, No 6.)

7 Anonymous. Requirements for thoracic medicine: a document for the guidance of those planning thoracic medical services and consultant posts. Br J Dis Chest 1984;78:303-4. 